\title{
Induced Mutations through EMS Treatment and In Vitro Screening for Salt Tolerance Plant of Petunia $\times$ atkinsiana D. Don
}

\author{
Marcelina KRUPA-MAŁKIEWICZ ${ }^{1 *}$, Alicja KOSATKA ${ }^{1}$, \\ Beata SMOLIK ${ }^{2}$, Maja SĘDZIK ${ }^{2}$ \\ ${ }^{1}$ West Pomeranian University of Technology in Szczecin, Faculty of Environmental Management and Agriculture, \\ Department of Plant Genetics, Breeding and Biotechnology, 17 Stowackiego str., 71-434 Szczecin, \\ Poland;mkrupa@zut.edu.pl(*correspondingauthor);alicja.kosatka@zut.edu.pl \\ ${ }^{2}$ West Pomeranian University of Technology in Szczecin, Faculty of Environmental Management and Agriculture, Department of Plant \\ Physiology and Biochemistry, 17 Stowackiego str.,71-434 Szczecin,Poland; beata.smolik@zut.edu.pl; maja.sedzik@zut.edu.pl
}

\begin{abstract}
In vitro culture is a practical plant breeding tool in developing plant resistant to different abiotic stresses such as salinity. In this study, the focus is on inducing mutations for salt tolerance using ethyl methane sulphonate (EMS) in calli of petunia (Petunia $\times$ atkinsiana D. Don 'Prism Red'), followed by cell line selection and subsequent plant regeneration. Callus cultures were initiated from leaf fragments soaked in mutagen solution in two concentrations 0.5 and $5.0 \mathrm{mM}$ for 60,120 and $180 \mathrm{~min}$, respectively. Then, the callus was rinsed three times in deionized, sterile water and was transferred onto embryo formation medium Murashige and Skoog (MS) supplemented with $2.0 \mathrm{mg} \mathrm{l}^{-1} 1$-napthaleneaceticacid (NAA) and $5.0 \mathrm{mg} \mathrm{l}^{-1}$ (6benzyloaminopurine) BAP. After 28 days, somatic embryos were transferred onto MS medium supplemented with $4.0 \mathrm{mg} \mathrm{l}^{-1}$ BAP for regeneration. Results of our studies showed that the callus immersion in the $5.0 \mathrm{mM}$ EMS solution caused damage to the cells, and indicated by the change in callus colour into brown. The plants regenerated from the somatic embryos induced from callus treated with $0.5 \mathrm{mM}$ solution of mutagen for 60 and 120 min were determined as M1 and M2 mutant variants, respectively. After the multiplication of the obtained plants, their tolerance to salinity stress was determined. The obtained results have showed that the M1 and M2 mutant lines were characterized by elevated tolerance to the stress factor in comparison to non-mutated plants.
\end{abstract}

Keywords: chemical mutagen, micro propagation, salinity stress

\section{Introduction}

The genus Petunia is a plant of high economic importance in world-wide horticulture and provides a model plant for studying plant development, due to various favourable biological features and the availability of technical tools for genomic, biochemical, cytogenetic and functional analyses (Berenschot et al., 2008).

Salt solution is one of the abiotic factors that influences growth and vigor of many crops. However, a negative influence of salinity not only reduces horticultural production with the concomitant increase of its costs, but it also causes soil erosion and disturbs the ecological balance (Manchanda and Garg, 2008; Piwowarczyk et al., 2016). High concentration of salt in the environment may cause stress in plants in two ways: by the increase in osmotic potential of the rooting medium as a result of high solute content, and by the toxic effect of high concentration of ions (Demir and Kocaçalişkan, 2002). The first way causes inhibition of the capability to absorb water from the substrate, contributing to the inhibition of growth of the plant subject to salinity stress. The second way is a longlasting process, stemming from the disturbance of the watermineral balance of plants, via accumulation of high concentrations of $\mathrm{Na}^{+}$and $\mathrm{Cl}^{-}$ions in the cells (Khalid et al., 2015).

Plants show a wide spectrum of response to salinity but all have their growth or/and field reduced by salt. Thus, the effect of salinity constitutes a result of many reactions that take place in the processes of morphological, physiological and biochemical changes within the plant (Sabir et al., 2012). Plants subject to salt stress are characterized by a clear decrease of plant tissue dry weight, increase of the root length to stem length ratio, a decrease of the area of leaves, eventually leading to yield reduction (Manchanda and Garg, 2008; Khalid et al., 2015; Piwowarczyk et al., 2016). Moreover, a high concentration of salts in the substrate influences the basic metabolic processes of 
the plant, such as photosynthesis or lipid metabolism (Agami, 2014). Large amount of salt can be accumulated in chloroplasts and cause damage of photosynthetic pigments, lowering leaf area or by decreasing the activity of photosynthetic enzymes (Nandy et al., 2007; Khalid et al., 2015; Piwowarczyk et al., 2016). In addition, salinity has a negative effect on cell membranes, causing lipid peroxidation, which, as a consequence, leads to malondialdehyde (MDA) accumulation (Khalid et al., 2015).

The understanding of the mechanisms enabling the tolerance of salt stress at the level of the entire organism and at molecular level is the key element, which would enable the improvement of tolerance to salinity of many crops (Piwowarczyk et al., 2016). Proper selection of tolerant genotypes from cultivated plants depends on the availability of verified assessment methods. Conventional breeding by hybridization or cross-pollination usually takes longer, yet sometimes also carries unexpected traits. This may result in an output that is not good as expected as a commercial cultivar (Rai et al., 2010; Gaswanto et al., 2016). Mutation is one of possible alternatives to conventional breeding for crop improvement program (López Colomba et al., 2013; Gaswanto et al., 2016; Oladosu et al., 2016; Purnamaningsih and Hutami, 2016). Genetic variability as a result of induced mutations by various mutagens has contributed to plant breeding efforts. It has played a major role, along with recombinant and transgenetic breeding, in the development of superior plant varieties demonstrating economic value of the mutation breeding technology. Mutagenesis is the process that causes changes in the genetic material via the use of chemical, physical or biological agents (Oladosu et al., 2016). The most commonly used chemical mutagens include ethyl methane sulfonate (EMS), which is characterized by causing the highest frequency of genetic changes and lowest frequency of chromosome aberrations in plant (van Harten, 1998). The chances of a mutation depend on the number, age and the growth stages of plant which are used as plant material (explant). The mutation frequency can be increased via the use of callus tissue as the starting material (Shalaby and El-Banna, 2013; Oladosu et al., 2016; Purnamaningsih and Hutami, 2016). Callus consists of a shapeless mass of non-differentiated and rapidly dividing cells (Purnamaningsih and Hutami, 2016). Moreover, according to Patade and Suprasanna (2008), genetic instability and somaclonal variation of callus tissue might considerably increases the chances of a mutation.

The evaluation of salt tolerance in tissue culture may be more useful for breeding programs, because selection is earlier and faster in tissue culture than in the field (Sabir et al., 2012). However, the determination of the proper dose of EMS mutagen is necessary to obtain useful mutants, without the excessive cell destruction and/or inhibition of embryo germination, with concomitant maintaining of regeneration. The objective of the present study was to obtain salt tolerant genotypes via application of EMS on calli of petunia followed by in vitro plant regeneration.

\section{Materials and Methods}

\section{Biologicalmaterial}

The research was conducted in a Department of Plant Genetics, Breeding and Biotechnology, West Pomeranian University of Technology in Szczecin (Poland). The plant of petunia (Petunia $\times$ atkinsiana D. Don) cultivar 'Prism Red' was used in the present study. Auxiliary buds from stabilized sterile in vitro culture were collected. Explants were cultured on plant growth regulators free MS (Murashige and Skoog, 1962) medium. After 4 weeks of culture, leaf segments were collected and cut into small pieces of about $10 \times 10 \mathrm{~mm}$.

\section{Experimental procedures}

For callus induction MS medium were supplemented with $5.0 \mathrm{mg} \mathrm{l}^{-1}$ BAP (6-benzyloaminopurine) and $3.0 \mathrm{mg} \mathrm{l}^{-1} \mathrm{IAA}$ (indole-3 acetic acid). Callus culture was incubated in flask containing $20 \mathrm{ml}$ medium. After 30 days, calli were cut into 2-3 $\mathrm{mm}^{3}$ clumps and soaked in solution of EMS in concentration 0.5 and $5.0 \mathrm{mM}$ for 1,2 and $3 \mathrm{~h}$. There were 40 clumps for each dose. After EMS treatment, the clumps were rinse tree times in sterile distillate water and cultured on MS medium without the addition of plant growth regulators. In preliminary experiment showed that long time of subculture reduced the regeneration rate, so calli culture were subcultured 4 times ( 21 days each). Percentage of live callus and callus colour were observed. The survived callus were regarded as mutant cell lines and transferred onto somatic embryo formation MS medium supplemented with $2.0 \mathrm{mg} \mathrm{l}^{-1} \mathrm{NAA}$ (1-napthaleneaceticacid) and $5.0 \mathrm{mg} \mathrm{l}^{-1}$ BAP. The selection of plant growth regulators was used on the basis of preliminary studies. After 4 weeks, the formed somatic embryos were transferred to regenerative MS medium supplied with $4.0 \mathrm{mg} \mathrm{l}^{-1} \mathrm{BAP}$. Thus regenerated plants were propagated 4 times on the MS medium without the addition of plant growth regulators.

In order to evaluate the level of tolerance of the obtained mutants to salinity stress, 3 combinations of media with different $\mathrm{NaCl}$ content $(50,100$ and $150 \mathrm{mM})$ were used. Petunia plants regenerated from callus and not treat of the EMS constituted the control. Two cm fragments of stems of the obtained mutants and control plants were placed on the proper media.

All cultures were incubated in growth room at the temperature of $25{ }^{\circ} \mathrm{C}$ under 16-h photoperiod with a photosynthetic photon flux density (PPFD) of $40 \mu \mathrm{mol} \mathrm{m}^{-2} \mathrm{~s}^{-1}$. All the media were contained with $8 \mathrm{gl}^{1}$ agar (Biocorp, Poland), $30 \mathrm{gl}^{-1}$ sucrose and $100 \mathrm{mg} \mathrm{l}^{-1}$ myo-inositol, $\mathrm{pH}$ was adjusted to 5.7. The media were heated and $30 \mathrm{ml}$ were poured into $450 \mathrm{ml}$ flask and next they were autoclaved at $121^{\circ} \mathrm{C}(0.1 \mathrm{MPa})$ during the time required according to the volume of medium in the vessel.

After 35 days explants were removed and washed with deionized distilled water, and the length of the shoots and roots $(\mathrm{cm})$, and the number of roots were measured. The plants were weighed for estimation of plant fresh mass (g) and were dried at $70^{\circ} \mathrm{C}$ for $48 \mathrm{~h}$. The dried plants were weighed to establish a plant dry mass $(\mathrm{g})$.

\section{Estimation of electrical conductivity}

Leaf discs of $1 \mathrm{~cm}^{2}$ were washed with distilled deionized water and placing in a test tube containing $10 \mathrm{ml}$ distilled water and incubated at $25^{\circ} \mathrm{C}$ on shaker $(100 \mathrm{rpm})$ for $24 \mathrm{~h}$. At the end of incubation the electrolytic conductivity I (EC I) of bathing solution was recorded (Electrical Conductivity Meter). The samples were autoclaved at $121{ }^{\circ} \mathrm{C}$ for 19 min to completely decompose the tissues and release electrolytes. EC II was recorded after cooling the solution to room temperature. Electrical conductivity was measured using the formula:

$$
\mathrm{EC}(\%)=(\mathrm{ECI} / \mathrm{EC} \mathrm{II}) \times 100
$$


192

\section{Determination of proline and $M D A$ content}

The concentration of free proline in petunia plants has been measured in three replications. The proline accumulation was determined according to Bates (1973). Content of the malondialdehyde (MDA) in plant tissue was determined by the method described by Sudhakar et al. (2001).

\section{Determination of pigments}

The levels of chlorophyll $a, b$ and carotenoid (Car) were measured in $80 \%(\mathrm{v} / \mathrm{v})$ acetone extracts according to Arnon $e t$ al. (1956) in modification to Lichtenthaler and Wellburn (1983). The concentration of $\mathrm{Chl} a$ and $\mathrm{Chl} b$ were calculated from equations derived by Hendry and Grime (1993).

fw] $\times \mathrm{V}$

Chlorophyll $a\left(\mathrm{mgg}^{-1} \mathrm{fw}\right)=\left[\left(12.7 \mathrm{~A}_{663}-2.69 \mathrm{~A}_{645}\right) / 1,000 \times\right.$ $\mathrm{fw}] \times \mathrm{V}$

Chlorophyll $b\left(\mathrm{mgg}^{-1} \mathrm{fw}\right)=\left[\left(22.9 \mathrm{~A}_{645}-4.68 \mathrm{~A}_{663}\right) / 1,000 \times\right.$

Carotenoid content was determined by the equation of Price and Henry (1991):

Carotenoid $\left(\mathrm{mg} \mathrm{g}^{-1} \mathrm{fw}\right)=\left[\left(\mathrm{A}_{480}+0.114 \mathrm{~A}_{663}\right)-\left(0.638 \mathrm{~A}_{663}\right)\right.$ $\times \mathrm{V} / 112.5 \times \mathrm{fw}]$

where $\mathrm{V}$ is volume of the sample $(\mathrm{ml}), \mathrm{A}$ is absorbance and $\mathrm{fw}$ is fresh weight $(\mathrm{g})$.

\section{Leafpigmentation}

The leaf pigmentation measurement was carried out using spectrophotometer CM-700d (Konica Minolta, Japan), in glass cuvettes of $1 \mathrm{~mm}$ optical length. Measurements were made in CIE L ${ }^{*}{ }^{*} b^{*}$ system, in which $L^{*}$ stands for white (100) and black colour $(0), \mathrm{a}^{*}$ - green $(-100)$ and red colour $(+100)$, $\mathrm{b}^{*}$ - blue (100) and yellow colour $(+100)$ (Hunterlab 2012). The $10^{\circ}$ observer type and D65 illuminant was applied. Colour was measured in triplicates for each experimental combination.

\section{Statistical analysis}

Results obtained for plants in in vitro cultures were statistically analysed. The significance of differences was determined by means of variance analysis (ANOVA) and Tukey's test, at the level of significance of $\alpha=0.05$. Homogenous groups between analysed combinations were labelled with successive letters of alphabet.

\section{Results and Discussion}

\section{Effect of EMS on callus tissue}

Callus, which was soaked in EMS solution, showed different growth responses depending on the time of immersion and concentration used. Moreover, the treated explants showed considerable differences in callus coloration (Fig. 1). In general, it was determined, that the callus tissue viability decreased with the increase of treatment time and mutagen concentration (Table 1).

The highest percentage $(100 \%)$ and the highest weight $(2.47 \mathrm{~g})$ of regenerated callus were observed on the control medium (without EMS). The use of $5.0 \mathrm{mM}$ EMS, independent of the treatment time, caused death of the entire callus tissue. 50 and $33.3 \%$ of calli treated by $0.5 \mathrm{mM}$ EMS for 1 and $2 \mathrm{~h}$ respectively were viable, so these ones were selected for the subsequent experiment. However, $0.5 \mathrm{mM}$ concentration for $3 \mathrm{~h}$ was highly toxic and gave adverse effect of calli proliferation. Callus of putative mutants of petunia which were able to withstand mutagenic treatment could develop shoot after being transferred onto the somatic embryo formation medium. The highest mean number of germinated embryos (2.1) was formed on the callus tissue on the control medium. However, it was observed, that with the increase of time of treatment of $0.5 \mathrm{mM}$ EMS solution the number of germinated somatic embryos decreased (Table 2). From the germinated somatic embryos, a somaclonal plant population was obtained, originating from the callus tissue treated with 0.5 $\mathrm{mM}$ EMS for $1 \mathrm{~h}$ (M1) and $0.5 \mathrm{mM}$ EMS for $2 \mathrm{~h}$ (M2). Svetleva and Crinó (2005) treating callus of common bean with EMS and NEU (N-nitrose-N'-ethyl urea) mutagens observed, that in both cases mutagen application of $90 \mathrm{~min}$ caused two relevant effect, either browning or callus growth inhibition. For the study conducted by Koch et al. (2012) a significant reduction in sugarcane plantlet production was observed at 32.2 to $96.6 \mathrm{mM}$ EMS. However, Revathi and Arumugam Pillai (2015) noticed that the lowest rice callus regeneration frequency was observed less than $120 \mathrm{~min}$ of exposure to $0.5 \%$ EMS. Purnamaningsih and Hutami (2016) using the EMS mutagen onto the sugarcane callus tissue determined, that the variability of the callus decreased with the increase of the mutagen concentration ( 0.1 to $0.5 \%)$ and time of its effect (30 to $120 \mathrm{~min}$ ). According to many authors (Bhagwat and Duncan 1998; Koh and Davies 2001; Latado et al., 2004; Svetleva and Crinó, 2005; Gadakh et al., 2015; Revathi and Arumugam Pillai, 2015) the use of $0.5 \%$ EMS solution is sufficient to obtain visible changes resulting from mutation. Koch et al. (2012) suggest that in order to increase the frequency of desired mutations, the mutagen concentration, in the range from 8 to $40 \mathrm{mM}$, should be used, and its exposure time should be $3 \mathrm{~h}$. However, response of the callus tissue to the effect of EMS is variable and it depends on plant genotype, and the concentration of mutagen. Induced chemical mutation can be successfully employed not only for early maturity (Gadakh et al., 2015; Oladosu et al., 2016), but also for induction of salt tolerance in sweet potato (Luan $e t$ al., 2007), rice (Revathi and Arumugam Pillai, 2015); low pH media and Al tolerance in sugarcane (Purnamaningsih and Hutami, 2016), and herbicide tolerance in sugarcane (Koch $e t$ al., 2012).

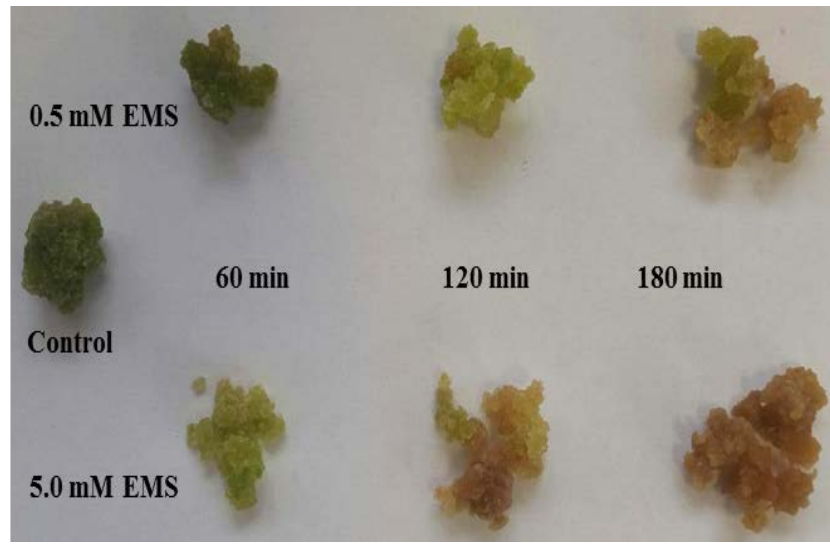

Fig. 1. Callus culture of Petunia $\times$ atkinsiana D. Don on MS medium after 0.5 and $5.0 \mathrm{mM}$ EMS treatment in different time $(60,120$ and $180 \mathrm{~min})$ 
Table 1. The percent (\%), weight (g) and colour of petunia's callus after immersion in 0.5 and $5.0 \mathrm{mM}$ EMS solution

\begin{tabular}{ccccc}
\hline $\begin{array}{c}\text { Time of immersion } \\
\text { in EMS solution }\end{array}$ & $\%$ & Callus weight $(\mathrm{g})$ & $\begin{array}{c}\text { Colour of } \\
\text { callus }\end{array}$ \\
\hline Without immersion & 100 & 2.47 & $\mathrm{a}$ & green \\
$60 \min 0.5 \mathrm{mM}$ & 50 & 1.75 & $\mathrm{~b}$ & green \\
$120 \min 0.5 \mathrm{mM}$ & 33.3 & 1.36 & $\mathrm{~b}$ & light green \\
$180 \min 0.5 \mathrm{mM}$ & 10 & 0.75 & $\mathrm{c}$ & light brown \\
$60 \min 5.0 \mathrm{mM}$ & 0 & 0 & $\mathrm{~d}$ & brown \\
$120 \min 5.0 \mathrm{mM}$ & 0 & 0 & $\mathrm{~d}$ & brown \\
$180 \min 5.0 \mathrm{mM}$ & 0 & 0 & $\mathrm{~d}$ & brown \\
\hline
\end{tabular}

Means in the same column followed by the same letter are not significantly different $(\alpha<0.05$; Least Significant Differences test LSD)
Table 2. Number of germinated somatic embryo on MS medium after callus immersion in 0.5 and $5.0 \mathrm{mM}$ EMS solution

\begin{tabular}{cccc}
\hline $\begin{array}{c}\text { Time of immersion } \\
\text { in EMS solution }\end{array}$ & \multicolumn{2}{c}{$\begin{array}{c}\text { No. of germinated } \\
\text { somatic embryo }\end{array}$} & \% control \\
\hline Without immersion & 2.1 & a & 100 \\
$60 \min 0.5 \mathrm{mM}$ & 0.42 & $\mathrm{~b}$ & 20 \\
$120 \min 0.5 \mathrm{mM}$ & 0.21 & $\mathrm{c}$ & 10 \\
$180 \min 0.5 \mathrm{mM}$ & 0.1 & $\mathrm{~cd}$ & 5 \\
$60 \min 5.0 \mathrm{mM}$ & 0 & $\mathrm{~d}$ & 0 \\
$120 \min 5.0 \mathrm{mM}$ & 0 & $\mathrm{~d}$ & 0 \\
$180 \min 5.0 \mathrm{mM}$ & 0 & $\mathrm{~d}$ & 0 \\
\hline & $\mathrm{LSD}_{\alpha 0.05}=0.20$ &
\end{tabular}

Means in the same column followed by the same letter are not significantly different $(a<0.05$; Least Significant Differences test LSD

Table 3. Effect of $\mathrm{NaCl}$ stress on plant height $(\mathrm{cm})$, root length $(\mathrm{cm})$ and root number in Petunia $\times$ atkinsiana D. Don control and variants (M1, M2)

\begin{tabular}{|c|c|c|c|c|c|c|c|}
\hline $\mathrm{NaCl}$ concentration $(\mathrm{mM})$ & \multirow{2}{*}{$\begin{array}{l}\text { Plantlet } \\
\text { Control }\end{array}$} & \multicolumn{2}{|c|}{ Shoot length $(\mathrm{cm})$} & \multicolumn{2}{|c|}{ Root length $(\mathrm{cm})$} & \multicolumn{2}{|c|}{ No of roots } \\
\hline \multirow{3}{*}{50} & & 2.12 & $\mathrm{~d}^{*}$ & 5.93 & a & 4.0 & $\mathrm{~b}$ \\
\hline & M1 & 5.50 & $\mathrm{a}$ & 5.62 & $\mathrm{a}$ & 4.0 & b \\
\hline & M2 & 4.40 & $\mathrm{~b}$ & 5.34 & a & 5.75 & a \\
\hline \multirow[t]{2}{*}{ Mean } & & 4.02 & $\mathrm{a}$ & 5.64 & $\mathrm{a}$ & 4.58 & a \\
\hline & Control & 2.0 & $\mathrm{~d}$ & 0 & $\mathrm{a}$ & 0 & $\mathrm{c}$ \\
\hline \multirow[t]{2}{*}{100} & M1 & 4.38 & $\mathrm{~b}$ & 2.56 & c & 3.75 & b \\
\hline & M2 & 3.50 & $\mathrm{c}$ & 1.63 & $\mathrm{~b}$ & 0.75 & c \\
\hline \multirow[t]{2}{*}{ Mean } & & 3.29 & $\mathrm{ab}$ & 1.39 & $\mathrm{~b}$ & 1.5 & $\mathrm{~b}$ \\
\hline & Control & 1.81 & $\mathrm{~d}$ & 0 & c & 0 & c \\
\hline \multirow[t]{2}{*}{150} & M1 & 2.12 & $\mathrm{~d}$ & 0 & c & 0 & c \\
\hline & M2 & 2.06 & $\mathrm{~d}$ & 0 & c & 0 & c \\
\hline \multirow[t]{3}{*}{ Mean } & & 2.0 & $\mathrm{~b}$ & 0 & c & 0 & b \\
\hline & & \multicolumn{2}{|c|}{$\mathrm{LSD}_{\mathrm{I}}=0.66$} & \multicolumn{2}{|c|}{$\mathrm{LSD}_{\mathrm{I}}=1.21$} & \multicolumn{2}{|c|}{$\mathrm{LSD}_{\mathrm{I}}=1.38$} \\
\hline & & \multicolumn{2}{|c|}{$\mathrm{LSD}_{\mathrm{II}}=1.07$} & \multicolumn{2}{|c|}{$\mathrm{LSD}_{\mathrm{II}}=1.98$} & \multicolumn{2}{|c|}{$\mathrm{LSD}_{\mathrm{II}}=2.25$} \\
\hline
\end{tabular}

\section{Effect of salt stress on plant growth}

The population of petunia somaclones obtained in our study was tested on selective media with different $\mathrm{NaCl}$ content (50, 100 and $150 \mathrm{mM}$, respectively). The influence of salinity stress on plant growth is often determined from stem and root length measurements (Piwowarczyk et al., 2016). According to Queirós et al. (2007) low growth coefficient may suggest the occurrence of adaptive processes for stress conditions within the plant. Another assessment point of the salinity stress effect on the plants should be evaluation of plants dry weight (Munns, 2005; Khalid et al., 2015). Manchanda and Garg (2008) found, that the increase of salinity tolerance is strictly related to the growth or unchanged dry weight content in plant under salinity stress. From the results of own study it was determined, that the addition of $150 \mathrm{mM} \mathrm{NaCl}$ to the medium showed highly inhibitory influence on morphological parameters of all petunia plants (Table 3). However, variants M1 and M2 line at each stress level had higher shoot and root length, fresh weight and plant water content then control (Tables 3, 4). Phenotypic observations have shown that control plants were more exposed to the negative effect of salinity stress than mutants, which is expressed by the lack of roots formed after the treatment with $100 \mathrm{mM}$ solution of $\mathrm{NaCl}$. Moreover, with the increase of salt concentration on the MS medium, the value of fresh and dry weight content in plants decreased (Table 4). In this case, the percentage of water content in the plant on the media with 100 and $150 \mathrm{mM} \mathrm{NaCl}$ was at similar level (Table 4). The addition of $\mathrm{NaCl}$ to the medium also had also a clear effect on electric conductivity (EC) in the plants (Table 4). It was observed, that with the increase of ion concentration the EC index was higher. Hence, control petunia plants were characterized by a higher EC index (44.4$60.0 \%$ ) in comparison to the introduced variants M1 (58.570.1\%) and M2 (59.4-74.06\%). This was probably influenced by the higher growth rate of these explants in the initial phase of the culture in comparison to the remaining plants.

\section{Effect of salt stress on biochemical parameters}

The capability of the plants to grow under the salinity stress depends to a large extent on the proper functioning of the osmotic balance. In plants exposed to salinity stress such mechanism might be manifested by the accumulation of inorganic ions or organic compounds. In opinion of many authors (Demir and Kocaçalişkan, 2002; Bybordi, 2012; Smolik et al., 2013; Krupa-Matkiewicz et al., 2015) elevated proline and MDA level in plant tissues is quite good indicator of a negative effects of various stress factors to a plant. Excessive proline accumulation occurs at a strong action of environmental stress, which results from its uncontrolled biosynthesis, limited oxidation, inhibition of its incorporation into proteins, and even release from proteins due to proteolysis (Girija et al., 2002). Many studies demonstrate that plants tolerant to salinity accumulate more proline, than sensitive plants. According to Abdelhamid et al. (2013) MDA is one of the end products that are produced as a result of lipid peroxidation damage by free radical. These conclusions are confirmed with the results of this study, where in all studied plants grown on the medium supplied with $150 \mathrm{mM} \mathrm{NaCl}$, a considerable increase of proline concentration and slight decrease of MDA concentration were observed (Table 5). 
194

Table 4. Effect of $\mathrm{NaCl}$ stress on fresh (g) and dry weight (g) of plants, plant water content (\%) and electric conductive (\%) in Petunia $\times$ atkinsiana D.

Don control and variants (M1, M2)

\begin{tabular}{|c|c|c|c|c|c|c|c|}
\hline \multirow[t]{2}{*}{$\begin{array}{c}\mathrm{NaCl} \text { concentration } \\
(\mathrm{mM})\end{array}$} & \multirow{2}{*}{$\begin{array}{l}\text { Plantlet } \\
\text { Control }\end{array}$} & \multicolumn{2}{|c|}{ Plant fresh weight (g) } & \multicolumn{2}{|c|}{ Plant dry weight $(\mathrm{g})$} & \multirow{2}{*}{$\begin{array}{c}\text { Plant water content }(\%) \\
94.03\end{array}$} & \multirow{2}{*}{$\frac{\mathrm{EC}(\%)}{44.4}$} \\
\hline & & 2.18 & $\mathrm{a}^{*}$ & 0.13 & $\mathrm{a}$ & & \\
\hline \multirow[t]{2}{*}{50} & M1 & 1.20 & b & 0.12 & $\mathrm{ab}$ & 90.0 & 58.5 \\
\hline & M2 & 1.24 & $\mathrm{~b}$ & 0.09 & b & 92.74 & 59.4 \\
\hline Mean & & 1.54 & $\mathrm{a}$ & 0.11 & $\mathrm{a}$ & 92.26 & 54.1 \\
\hline \multirow{3}{*}{100} & Control & 1.57 & $\mathrm{a}$ & 0.09 & $\mathrm{a}$ & 94.26 & 54.6 \\
\hline & M1 & 0.34 & $\mathrm{~b}$ & 0.04 & $\mathrm{~b}$ & 88.23 & 61.48 \\
\hline & M2 & 0.58 & b & 0.06 & $\mathrm{ab}$ & 89.65 & 66.9 \\
\hline Mean & & 0.83 & $a b$ & 0.06 & $\mathrm{a}$ & 90.71 & 57.66 \\
\hline \multirow{3}{*}{150} & Control & 0.19 & $\mathrm{a}$ & 0.07 & $\mathrm{a}$ & 63.16 & 60.0 \\
\hline & M1 & 0.54 & $\mathrm{a}$ & 0.05 & $\mathrm{ab}$ & 90.74 & 70.1 \\
\hline & M2 & 0.28 & $\mathrm{a}$ & 0.03 & b & 89.28 & 74.06 \\
\hline \multirow[t]{3}{*}{ Mean } & & 0.34 & b & 0.05 & $\mathrm{a}$ & 81.06 & 61.38 \\
\hline & & \multicolumn{2}{|c|}{$\mathrm{LSD}_{\mathrm{I}}=0.66$} & \multicolumn{2}{|c|}{$\mathrm{LSD}_{\mathrm{I}}=0.66$} & & \\
\hline & & \multicolumn{2}{|c|}{$\mathrm{LSD}_{\mathrm{II}}=1.07$} & \multicolumn{2}{|c|}{$\mathrm{LSD}_{\mathrm{II}}=1.07$} & & \\
\hline
\end{tabular}

Table 5. Effect of $\mathrm{NaCl}$ stress on proline and MDA concentration in

Petunia $\times$ atkinsiana D. Don control and variants (M1, M2)

\begin{tabular}{|c|c|c|c|c|c|}
\hline \multirow[t]{2}{*}{$\begin{array}{c}\mathrm{NaCl} \\
\text { concentration } \\
(\mathrm{mM}) \\
\end{array}$} & \multirow{2}{*}{$\begin{array}{l}\text { Plantlet } \\
\text { Control }\end{array}$} & \multicolumn{2}{|c|}{$\begin{array}{c}\text { Proline } \\
\left(\mu \mathrm{mol} \mathrm{g}^{-1} \mathrm{fw}\right)\end{array}$} & \multicolumn{2}{|c|}{$\begin{array}{c}\text { MDA } \\
\left(\mathrm{nmol} \mathrm{g}^{-1} \mathrm{fw}\right)\end{array}$} \\
\hline & & 5.88 & $\mathrm{~b}^{*}$ & 13.79 & $\mathrm{a}$ \\
\hline \multirow[t]{2}{*}{50} & M1 & 10.95 & $\mathrm{a}$ & 13.22 & a \\
\hline & M2 & 10.77 & $\mathrm{a}$ & 12.89 & a \\
\hline \multirow[t]{2}{*}{ Mean } & & 9.20 & c & 11.79 & a \\
\hline & Control & 10.57 & $\mathrm{~b}$ & 13.62 & a \\
\hline \multirow[t]{2}{*}{100} & M1 & 17.09 & $\mathrm{a}$ & 12.81 & a \\
\hline & M2 & 17.03 & $\mathrm{a}$ & 12.81 & a \\
\hline \multirow[t]{2}{*}{ Mean } & & 14.89 & $\mathrm{~b}$ & 13.08 & a \\
\hline & Control & 9.65 & $\mathrm{c}$ & 9.27 & a \\
\hline \multirow[t]{2}{*}{150} & M1 & 43.22 & $\mathrm{a}$ & 10.64 & a \\
\hline & M2 & 38.50 & b & 10.88 & a \\
\hline \multirow[t]{3}{*}{ Mean } & & 30.46 & $\mathrm{a}$ & 11.77 & $\mathrm{a}$ \\
\hline & & \multicolumn{2}{|c|}{$\mathrm{LSD}_{\mathrm{I}}=3.71$} & \multicolumn{2}{|c|}{$\mathrm{LSD}_{\mathrm{I}}=2.05$} \\
\hline & & \multicolumn{2}{|c|}{$\mathrm{LSD}_{\mathrm{II}}=3.04$} & \multicolumn{2}{|c|}{$\mathrm{LSD}_{\mathrm{II}}=1.66$} \\
\hline
\end{tabular}

According to many authors (Demir and Kocaçalişkan, 2002; Bybordi, 2012; Krupa-Małkiewicz et al., 2015; Piwowarczyk et al., 2016) salinity stress has a negative effect on the photosynthetic pigment content, which constitutes an effect of photosynthetic apparatus degradation. In presented studies, salinity stress induced by $50 \mathrm{mM} \mathrm{NaCl}$ decrease the contents of chlorophylls in M1 and M2 variants (Chl $a$ by 25 and $18 \%$, respectively; Chl $b$ by 18 and $22 \%$, respectively) and increase carotenoid content (by 19 and 63\% respectively), in comparison to the control plants (Table 6). In addition, it was observed that increase of $\mathrm{NaCl}$ concentration in $\mathrm{MS}$ medium caused decrease in Chl $a$ and Car concentrations in all analyzed petunia genotypes (control, M1 and M2). However, the injurious effect of 100 and $150 \mathrm{mM}$ salinity was more striking in control than $\mathrm{M} 1$ and $\mathrm{M} 2$ variants.

Content of photosynthetic pigments in petunia 'Prism Red' leaves is closely correlated to their colour (Fig. 2). Although leaves of petunia from the medium supplemented with 50 and $100 \mathrm{mM} \mathrm{NaCl}$ salt were at the same level of darkness and green colour. It is evidence by the value of $\mathrm{L}^{*}$ and a parameters (Fig. 2). It was observed that increasing in the

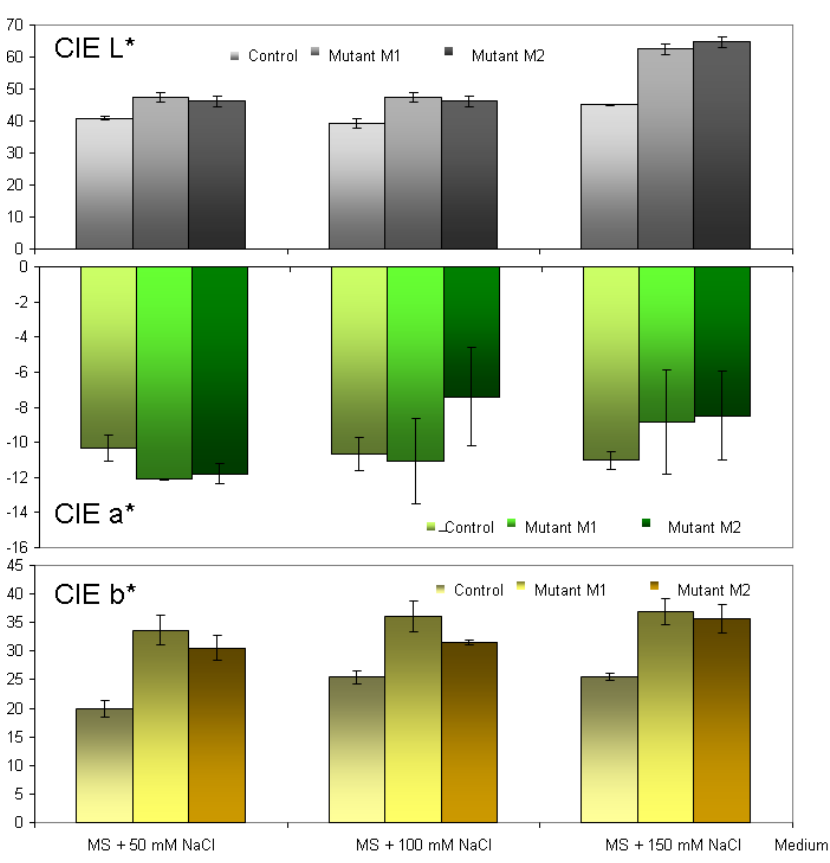

Fig. 2. Effect of $\mathrm{NaCl}$ stress on leaves colour space using $\mathrm{CIE}$ $\mathrm{L}^{*} \mathrm{a}^{*} \mathrm{~b}^{*}$ system, $\mathrm{L}^{*}$ the lightness coefficient, $\mathrm{a}$ (green colour) and $\mathrm{b}^{*}$ (yellow colour) in Petunia $\times$ atkinsiana D. Don control (C) and mutants (M1, M2)

medium concentration of $\mathrm{NaCl}$ to $150 \mathrm{mM}$, the value of $\mathrm{L}$ parameter was higher in comparison to control by 13.5 and $17.6 \%$ (M1 and M2, respectively). Moreover, all petunia plants tested from the medium supplied with $150 \mathrm{mM} \mathrm{NaCl}$ were characterized by lighter leaf coloration in comparison to the remaining experimental combinations. This is showed by the value of the $b^{*}$ parameter, which has a clear increase tendency (Fig. 2).

\section{Conclusions}

The conducted review has shown that some man-made and disturbed habitats host many rare orchids and could provide a chance for survival of those rare and valuable plant species. The need for the protection of sites of valuable orchid species in habitats strongly transformed by man should be taken into consideration at the present time. 
Table 6. Effect of $\mathrm{NaCl}$ stress on chlorophyll $a, b(\mathrm{Chl} a, \mathrm{Chl} b)$ and carotenoid (Car) concentration in Petunia $\times$ atkinsiana D. Don control and variants $(\mathrm{M} 1, \mathrm{M} 2)$

\begin{tabular}{|c|c|c|c|c|c|c|c|}
\hline $\mathrm{NaCl}$ concentration $(\mathrm{mM})$ & \multirow{2}{*}{$\begin{array}{l}\text { Plantlet } \\
\text { Control }\end{array}$} & \multicolumn{2}{|c|}{$\begin{array}{c}\mathrm{Chl} a \\
\left(\mathrm{mg} \mathrm{g}^{-1} \mathrm{fw}\right)\end{array}$} & \multicolumn{2}{|c|}{$\begin{array}{c}\mathrm{Chl} b \\
\left(\mathrm{mgg}^{-1} \mathrm{fw}\right)\end{array}$} & \multicolumn{2}{|c|}{$\begin{array}{c}\text { Car } \\
\left(\mathrm{mg} \mathrm{g}^{-1} \mathrm{fw}\right)\end{array}$} \\
\hline \multirow{3}{*}{50} & & 94.41 & $a^{*}$ & 14.93 & $\mathrm{a}$ & 3.57 & $\mathrm{~b}$ \\
\hline & M1 & 70.91 & $\mathrm{c}$ & 12.24 & $\mathrm{a}$ & 4.25 & $\mathrm{~b}$ \\
\hline & M2 & 77.56 & $\mathrm{~b}$ & 11.69 & a & 5.81 & a \\
\hline Mean & & 80.96 & $\mathrm{a}$ & 12.95 & $\mathrm{a}$ & 4.54 & $\mathrm{a}$ \\
\hline \multirow{3}{*}{100} & Control & 54.69 & $\mathrm{~b}$ & 11.16 & $\mathrm{~b}$ & 2.16 & $\overline{\mathrm{a}}$ \\
\hline & M1 & 61.96 & $\mathrm{a}$ & 13.61 & $\mathrm{~b}$ & 3.37 & $\mathrm{a}$ \\
\hline & M2 & 63.40 & $\mathrm{a}$ & 18.23 & $\mathrm{a}$ & 3.58 & $\mathrm{a}$ \\
\hline \multirow[t]{2}{*}{ Mean } & & 60.02 & $\mathrm{~b}$ & 14.33 & $\mathrm{a}$ & 3.03 & $\mathrm{~b}$ \\
\hline & Control & 37.32 & $\mathrm{a}$ & 7.39 & $\mathrm{~b}$ & 0.51 & $\mathrm{a}$ \\
\hline \multirow[t]{2}{*}{150} & M1 & 36.92 & $\mathrm{a}$ & 12.11 & $\mathrm{a}$ & 0.86 & $\mathrm{a}$ \\
\hline & M2 & 38.97 & $\mathrm{a}$ & 15.39 & $\mathrm{a}$ & 0.76 & $\mathrm{a}$ \\
\hline \multirow[t]{3}{*}{ Mean } & & 37.74 & $\mathrm{c}$ & 11.63 & $\mathrm{a}$ & 0.71 & $\mathrm{c}$ \\
\hline & & \multicolumn{2}{|c|}{$\mathrm{LSD}_{\mathrm{I}}=6.59$} & \multicolumn{2}{|c|}{$\mathrm{LSD}_{\mathrm{I}}=4.5$} & \multicolumn{2}{|c|}{$\mathrm{LSD}_{\mathrm{I}}=1.02$} \\
\hline & & \multicolumn{2}{|c|}{$\mathrm{LSD}_{\mathrm{II}}=5.37$} & \multicolumn{2}{|c|}{$\mathrm{LSD}_{\mathrm{II}}=3.67$} & \multicolumn{2}{|c|}{$\mathrm{LSD}_{\mathrm{II}}=0.87$} \\
\hline
\end{tabular}

\section{References}

Abdelhamid MT, Sadak MSH, Schmidhalter U, El-Saady AKM (2013). Interactive effects of salinity stress and nicotinamide on physiological and biochemical parameters of faba bean plant. Acta Biológica Columbiana 18:499-510.

Agami RA (2014). Applications of ascorbic acid or proline increase resistance to salt stress in barley seedlings. Biologia Plantarum 58:341-347.

Arnon DJ, Allen MB, Whatley F (1956). Photosynthesis by isolated chloroplast. Biochimica and Biophysica Acta 20:449-461.

Bates LS (1973). Rapid determination of free proline for water-stress studies. Plant and Soil 39:205-207.

Berenschot AS, Zucchi MI, Tulmann-Neto A, Quecini V (2008). Mutagenesis in Petunia $\times$ hybrida Vilm. and isolation of a novel morphological mutant. Brazilian Journal of Plant Physiology 20:16-27.

Bhagwat B, Duncan EJ (1998). Mutation breeding of banana cv. Highgate (Musa spp., AAA Group) for tolerance to Fusarium oxysporum $f$. sp. cubense using chemical mutagens. Scientia Horticulturae 73:11-22.

Bybordi A (2012). Effect of ascorbic acid and silicium on photosynthesis, antioxidant enzyme activity, and fatty acid contents in Canola exposure to salt stress. Journal of Integrative Agriculture 11:1610-1620.

Demir Y, Kocaçalişkan I (2002). Effect of $\mathrm{NaCl}$ and proline on bean seedlings cultured in vitro. Biologia Plantarum 45:597-599.

Gadakh SS, Patel DU, Patil AB (2015). Evaluation of sugarcane (Saccharum spp. complex) mutants for yield, yield contributing traits and quality parameters. International Journal of Advanced Biological Research 5:220-228.

Gaswanto R, Syukur M, Purwoko BS, Hidayat SH (2016). Induced mutation by gamma rays irradiation to increase chilli resistance to begomovirus. Agrivita, Journal of Agricultural Science 38(1):2432.

Girija C, Smith BN, Swamy PM (2002). Interactive effects of sodium chloride and calcium chloride on the accumulation of proline and gycinebetaine in peanut (Arachis hypogaea L.). Environmental and Experimental Botany 47:1-10.

Hendry GAF, Grime JP (1993). Methods in comparative plant ecology. Marcel DekkerInc, New York.
Hunterlab (2012). Measuring Colour using Hunter L, a, b versus CIE 1976

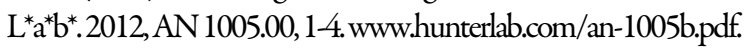

Khalid H, Kumari M, Grover A, Nasim M (2015). Salinity stress tolerance of Camelina investigated in vitro. Plant Science 46:137-144.

Koch AC, Ramgareeb S, Rutherford RS, Snyman SJ, Watt MP (2012). An in vitro mutagenesis protocol for the production of sugarcane tolerant to the herbicide imazapyr. In Vitro Cellular and Developmental Biology Plant 48:417-427.

Koh YC, Davies FT (2001). Mutagenesis and in vitro culture of Tillandsia fasciculate Swartz var. fasciculata (Bromeliaceae). Scientia Horticulturae 87:225-240.

Krupa-Małkiewicz M, Smolik B, Ostojski D, Sędzik M (2015). Effect of ascorbic acid on morphological and biochemical parameters in tomato seedling exposure to salt stress. Environmental Protection and Natural Resources 24:25-27.

Latado RR, Adames AH, Neto AT (2004). In vitro mutation of chrysanthemum (Dendrathema grandiflora Tzvelev) with ethylmethansulphonate (EMS) in immature floral pedicels. Plant Cell, Tissue and Organ Culture 77:103-106.

Lichtenthaler HK, Wellburn AR (1983). Determinations of total carotenoids and chlorophylls $a$ and $b$ of leaf extracts in different solvents. Biochemical Society Transactions 11:591-592.

López Colomba E, Tommasiono E, Luna C, Griffa S, Carloni E, Ribotta A, Quiroga M, Grunberg K (2013). Differential salt-stress response during germination and vegetative growth in in vitro selected somaclonal mutants of Cenchrus ciliaris L. South African Journal of Botany 87:157163.

Luan YS, Zhang J, Gao XR (2007). Mutation induced by ethylmethanesulphonate(EMS), in vitro screening for salt tolerance and plant regeneration of sweet potato (Ipomoea batatas L.). Plant Cell, Tissue and Organ Culture 88:77-81.

Manchanda G, Garg N (2008). Salinity and its effects on the functional biology oflegumes. Acta Physiologia Plantarum 30:595-618.

Munns R (2005). Genes and salt tolerance: bringing them together. New Phytologist 167:645-663. 
196

Murashige T, Skoog F (1962). A revised medium for rapid growth and bioassay with tobacco tissue culture. Physiologia Plantarum 15:473-497.

Nandy P, Das S, Ghose M, Spooner-Hart R (2007). Effects of salinity on photosynthesis, leaf anatomy, ion accumulation and photosynthetic nitrogen use efficiency in five Indian mangroves. Wetlands Ecology and Management 15:347-357.

Oladosu Y, Rafii MY, Abdullah N, Hussin G, Ramli A, Rahim HA, Miah G, Usmam M (2016). Principle and application of plant mutagenesis in crop improvement: a review. Biotechnology and Biotechnological Equipment 30(1):1-16.

Patade VP, Suprasanna P (2008). Radiation induced in vitro mutagenesis for sugarcane improvement. Sugar Tech 10:149.

Piwowarczyk B, Tokarz K, Kaminska I (2016). Response of grass pea seedlings to salinity stress in in vitro culture conditions. Plant Cell, Tissue and Organ Culture 124:227-240.

Price AH, Hendry GA (1991). Ion-catalyzed oxygen radical formation and its possible contribution to drought damages in nine native grasses and three cereals. Plant, Cell and Environment 14:477-484.

Purnamaningsih R and Hutami S (2016). Increasing Al-tolerance of sugarcane using ethyl methane sulphonate and in vitro selection in low pH media. Hayati Journal Bioscience 1-6. doi.org/10.1016/j.hjb.2016. 01.006 .

Queirós F, Fidalgo F, Santos I, Salema R (2007). In vitro selection of salt tolerant cell lines in Solanum tuberosum L. Biologia Plantarum 51:728734.
Rai MK, Kalia RK, Singh R, Gangola MP, Dhawan AK (2010). Developing stress tolerant plants through in vitro selection - An overview of the recent progress. Environmental and Experimental Botany 71(1):89-98.

Revathi S, Arumugam Pillai M (2015). In vitro callus induction and regeneration in fine grain rice variety Basmanti370. Life Sciences Leaflets 63:23-29.

Sabir F, Sangwan RS, Kumar R, Sangwan NS (2012). Salt stress-induced responses in growth and metabolism in callus cultures and different in vitro shoots of Indian ginseng (Withania somnifera Dunal). Journal of Plant Growth Regulation 31:537-548.

Shalaby TA, El-Banna A (2013). Molecular and horticultural characteristics of in vitro induced tomato mutants. Journal of Agricultural Science 5(10):155-163.

Smolik B, Miśkowiec A, Rekowska E, Zakrzewska H, Śnioszek M (2013). The influence of particular biostimulators on some biochemical parameters in broccoli (Brassica oleracea L. var. Botrytis italica Plenck). Environmental Protection and Natural Resources 24:25-27.

Svetleva DI, Crinó P (2005). Effect of ethyl methanesulfonate (EMS) and $\mathrm{N}$-nitrose-N-ethyl Urea (ENU) on callus growth of common bean. Journal ofCentral European Agriculture 6:59-64.

Sudhakar C, Lakshim A, Giridarakumar S (2001). Changes in the antioxidant enzyme efficacy in two high yielding genotypes of mulberry (Morus alba L.) under NaClsalinity. Plant Science 161:613-619.

Van Harten AM (1998). Mutation Breeding: Theory and Practical Applications. Cambridge University Press, London. 